\title{
Alleviation of chilling injury induced by cold quarantine treatment in Midknight Valencia and Lane Late sweet orange fruit
}

\author{
Muneer Rehman ${ }^{1}$, Zora Singh ${ }^{1} *$, Tahir Khurshid ${ }^{2}$ \\ ${ }^{1}$ Curtin Horticulture Research Laboratory, School of Molecular and Life Sciences, Faculty of Science and Engineering, \\ Curtin University, GPO Box U1987, Perth 6845, Western Australia \\ ${ }^{2}$ NSW Department of Primary Industries, Dareton, Australia
}

*Corresponding author: z.singh@curtin.edu.au; zora.horti@hotmail.com

\begin{abstract}
Cold quarantine treatment $\left(1^{\circ} \mathrm{C}\right.$ for 21 days) induces chilling injury $(\mathrm{Cl})$ in sweet orange fruit. We investigated the effects of different treatments such as hot water $\operatorname{dip}\left(H W D, 50^{\circ} \mathrm{C}\right.$ ) alone or combined with thiabendazole (TBZ) five-minute, different concentrations of salicylic acid (SA), methyl jasmonate (MJ) one-minute dip and fumigation of nitric oxide (NO) two-hour and ethylene (ET) (six-hour) on $\mathrm{Cl}$ and fruit quality following 21 days cold quarantine treatment and 10-day at ambient temperature in 'Lane Late' and 'Midknight Valencia' fruit. The experiment was laid out by following completely randomised design included three replications. HWD alone or combined with TBZ, or MJ significantly reduced $\mathrm{Cl}$ in both cultivars. NO $\left(5 \mu \mathrm{L} \mathrm{L}{ }^{-1}\right)$ fumigation significantly reduced weight loss in 'Lane Late' only as compared to all other treatments except SA (1, and $3 \mathrm{mM})$. SCC/TA ratio was significantly reduced with ethylene, HW alone or combined with TBZ or MJ $(0.25 \mathrm{mM})$ as compared to all other treatments in 'Midknight Valencia', but not in 'Lane Late'. The $\mathrm{NO}\left(10 \mu \mathrm{L} \mathrm{L}^{-1}\right)$ fumigation resulted in the significantly highest level of vitamin C only in 'Midknight Valencia'. SA (3 mM) dip treatment resulted in the significantly highest levels of total antioxidants as compared to all other treatments in 'Lane Late' but not in 'Midknight Valencia'. In conclusion, HWD alone or in combination with TBZ (20 mg L $\mathrm{L}^{-1}$ ) or $\mathrm{MJ}(0.50 \mathrm{mM})$ effectively reduced Cl caused after cold quarantine treatment without adversely affecting fruit quality.
\end{abstract}

Keywords: (Citrus sinensis L. Osbeck); Quarantine; Chilling injury; Fruit quality; Sweet orange.

Abbreviations: $\mathrm{Cl}_{-}$chilling injury; $\mathrm{Cl}_{-}$chilling injury percentage; $\mathrm{HW}_{-}$hot water; $\mathrm{HWD}_{-}$hot water dipping; $\mathrm{TBZ}_{-}$thiabendazole; MJ_methyl jasmonate; SA_salicylic acid; NO_ nitric oxide; ET_ethylene; MFF_ Mediterranean fruit fly; QFF_ Queensland fruit fly; USDA_ United States Department of Agriculture; $h_{-}^{\circ}$ hue angle; $\mathrm{CCl}_{-}$citrus colour index; POX _ peroxidase; CAT _ catalase; TP_ total phenolic content; HSPs_heat shock proteins; ROS_reactive oxygen species.

\section{Introduction}

Citrus is one of the most important fruit group in Australia with a total production of 470 MT in 2016-17 (USDA, 2017). Australia exports high quality fresh sweet oranges fruit (180 MT) during the off-season to markets of the Northern Hemisphere (USDA, 2017). In Australia, cold quarantine treatment against Mediterranean fruit fly [MFF; Ceratitis capitata (Diptera: Tephritidae)] and Queensland fruit fly [QFF; Bactrocera tryoni (Froggatt)] in the Western and Eastern regions respectively, is mandatory to comply with quarantine requirements of the importing countries (De Lima et al., 2007). Previously, fumigation with methyl bromide, irradiation and cold treatment were practised to disinfect the citrus fruit but currently the use of methyl bromide has been restricted in Australia because it shortens the storage life of citrus fruit due to its phytotoxic nature and also promotes ozone depletion (De Lima et al., 2007). Consumer demands, environmental factors and government regulations have led to research on adopting non-chemical methods for the post-harvest protection of horticulture commodities (Sharples, 1990). Cold quarantine treatment is a non-chemical, approved method for disinfestation of QFL and MFF. This involves the exposure of the sweet orange fruit to non-freezing temperatures $\left(1.1-2.2^{\circ} \mathrm{C}\right)$ for a period of 14-18 days (d) (Powell, 2003). However, the application of this treatment leads to the development of chilling injury (Cl) more or less in all citrus cultivars when kept at room temperature (Martinez-Téllez and Lafuente, 1997). The Cl symptoms mainly manifest as scalding, rind pitting, watery breakdown, development of a woolly or leathery texture and decay (Reuther et al., 1989). Cl negatively impacts the consumer preference and overall quality of the fruit. The sensitivity of the citrus fruit to low temperature causes serious economic implications for its export to the different fruit fly free zones of importing countries (US Department of Agriculture, Animal and Plant Protection Service, 1976).

Various approaches have been tested to minimise $\mathrm{Cl}$ in different fruit crops such as post-harvest hot water dipping (HWD), application of MJ or NO fumigation. Previously, HWD alone or in combination with TBZ reduced $\mathrm{Cl}$ in citrus fruit induced by cold quarantine in different cultivars of sweet oranges such as 'Washington Navel' and 'Valencia Late' (Bassal and El-Hamahmy, 2011), 'Tarocco', 'Moro', 
'Sanguinello' and 'Doppio Sanguigno' (Schirra et al., 2004), and 'Tarocco' (Palma et al., 2013). MJ has been previously reported to reduce $\mathrm{Cl}$ in different fruit crops such as lemon (Citrus limon Burm.f.) (Siboza at al., 2014), mangoes (Mangifera indica cv. 'Kent') (Gonzalez- Aguilar et al., 2000,), guava (Psidium guajava) (Gonzalez-Aguilar et al., 2004), peach (Prunus persica Batsch. cv. 'Baifeng') (Meng et al., 2009), loquat (Eriobotrya japonica Lindl.) (Cao et al., 2009), pomegranate (Punica granatum L.) (Mirdehghan and Ghotbi, 2014), pineapple (Ananas comosus L. Merr) (Nilprapruck et al., 2013), bell pepper (Capsicum annuum L.), avocado (Persea americana Mill.), and grapefruit (Citrus paradisi Macf.) (Meir et al., 1996). No research work has been reported on the efficacy of exogenously applied MJ in reducing $\mathrm{Cl}$ induced by cold quarantine treatment in sweet orange fruit. The application of salicylic acid alone and combined application of MJ and salicylic acid enhanced chilling tolerance in cold-stored pomegranate (Mirdehghan and Ghotbi, 2014), lemon fruit (Siboza and Bertling, 2013) and tomato (Ding et al., 2002), Nitric oxide (NO) is a free radical and highly reactive gas, acting as a multifunctional signalling molecule in various physiological responses (Wendehenne et al., 2001). NO has been reported to reduce chilling injury and maintain fruit quality in climacteric fruits such as Japanese plum cv 'Amber Jewel' (Singh et al., 2009), banana (Musa spp., AAA group cv. 'Cavendish') (Wang et al., 2013), peach cv. 'Feicheng') (Zhu et al., 2010) and mango cv. 'Kensington Pride') (Zaharah and Singh, 2011). Recently, Ghorbani et al. (2017) reported that $0.5 \mathrm{mM}$ SNP (sodium nitroprusside) 5 minute (min) dip treatment reduce $\mathrm{Cl}$ in 'Washington Navel' orange stored for five months at $3^{\circ} \mathrm{C}$. However, the efficacy of $\mathrm{NO}$ in reducing $\mathrm{Cl}$ induced by cold quarantine treatment in sweet oranges yet to be investigated. No research work has been reported on the effects of exogenous application of MJ, NO and SA on inducing chilling tolerance during cold quarantine treatment ( $1{ }^{\circ} \mathrm{C}$ for 21 days) in 'Lane Late' and 'Midknight Valencia' sweet orange fruit. It was hypothesised that exogenous postharvest application of MJ, NO and SA may induce chilling tolerance in sweet orange fruit when exposed to cold quarantine at $1{ }^{\circ} \mathrm{C}$ for 21 days. These observations prompted to investigate the effects of exogenous application of MJ, SA, NO, TBZ, and HW on the incidence of chilling injury induced by cold quarantine treatment $\left(1{ }^{\circ} \mathrm{C}\right.$ for 21 days) and fruit quality in sweet orange.

\section{Results}

\section{Chilling injury percentage}

$\mathrm{HW}$ dip at $50^{\circ} \mathrm{C}$ alone and combined with TBZ $\left(20 \mathrm{mg} \mathrm{L}^{-1}\right) 5$ min dip and $\mathrm{MJ}(0.50 \mathrm{mM}) 1 \mathrm{~min}$ dip have significantly $(P \leq$ $0.05)$ reduced the incidence of $\mathrm{Cl}(8.9,8.9$ and $15.6 \%$ respectively) as compared to the control (40.5\%) in 'Lane Late' sweet orange (Fig. 1). In 'Midknight Valencia', HW at $50^{\circ} \mathrm{C}$ alone or combined with TBZ for 5 min dip and MJ $(0.50$ $\mathrm{mM}$ ) significantly reduced $\mathrm{Cl}(8.8$ to $16.6 \%)$ as compared to the control (28.8\%) (Fig 2). Fruit dipped in $\mathrm{MJ}(0.50 \mathrm{mM})$ for $1 \mathrm{~min}$ exhibited the lowest percentage of $\mathrm{Cl}$ incidence as compared to all other treatments (Fig 2).

\section{Fruit Colour}

Citrus colour index $(\mathrm{CCl})$ was significantly affected by all treatments in 'Lane Late' sweet orange but not in 'Midknight
Valencia'. In 'Lane Late', MJ (0.10 mM) 1 min dip treatment resulted in significantly reduced $h^{\circ}(60.7)$ and increased CCI (8.7) as compared to the control and all other treatments (Table 1). In 'Midknight Valencia', TBZ $\left(20 \mathrm{mg} \mathrm{L}^{-1}\right)$ combined with HW 5 min dip treatment showed significantly reduced $h^{\circ}(61.2)$ as compared to the control and all other treatments (Table 1).

\section{Weight loss (\%) and fruit firmness (N)}

All the treatments significantly $(P \leq 0.05)$ affected percentage weight loss in 'Lane Late' sweet orange fruit but not in 'Midknight Valencia'. In 'Lane Late', NO fumigation (5

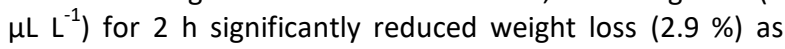
compared to the control $(6.0 \%)$ and all other treatments (Table 2). Fruit firmness (N) was not significantly affected by any of the treatments in both the cultivars (Table 2).

\section{SSC, TA and SCC/TA ratio}

All the treatments except $\mathrm{MJ}(0.50 \mathrm{mM}) 1 \mathrm{~min}$ dip resulted in significantly reduced SSC (\%) in the juice of 'Lane Late' sweet orange as compared to the control. However, in 'Midknight Valencia', SSC (\%) was reduced as compared to the control and all the treatments applied except ethylene $\left(10 \mu \mathrm{L} \mathrm{L}^{-1}\right)$ six $h$ fumigation, TBZ combined with HWD 5 min and NO (10 and $20 \mu \mathrm{L} \mathrm{L}^{-1}$ ) two h fumigation (Table 3). In 'Lane Late', TA (\%) and SSC/TA ratio were not significantly affected by any of the treatments applied (Table 3). Moreover, TA in 'Midknight Valencia' juice was significantly $(P \leq 0.05)$ highest (0.91 and $0.92 \%)$ when the fruit were fumigated with ethylene $\left(10 \mu \mathrm{L} \mathrm{L}^{-1}\right)$ for six $\mathrm{h}$ and $\mathrm{MJ}(0.25 \mathrm{mM})$ one min dip treatment, respectively. SSC/TA ratio in the juice of 'Midknight Valencia' was significantly higher in all the treatments except ethylene $\left(10 \mu \mathrm{L} \mathrm{L}^{-1}\right)$ six h fumigation, $\mathrm{HW}$ alone $5 \mathrm{~min}$ dip, TBZ combined with HW $1 \mathrm{~min}$ dip and MJ (0.25 mM) 1 min dip.

\section{Vitamin C and total antioxidants}

The concentrations of vitamin $\mathrm{C}$ in the juice were significantly $(P \leq 0.05)$ affected by all treatments in 'Midknight Valencia' but not in 'Lane Late'. In 'Midknight Valencia', all the treatments except ethylene $\left(10 \mu \mathrm{L} \mathrm{L}^{-1}\right) \mathrm{six} \mathrm{h}$ fumigation, MJ $(0.50 \mathrm{mM}) 1 \mathrm{~min}$ dip and $\mathrm{NO}\left(5\right.$ and $\left.10 \mu \mathrm{L} \mathrm{L}^{-1}\right)$ $2 \mathrm{~h}$ fumigation significantly reduced the concentrations of vitamin C in the juice as compared to the control $(295.9 \mathrm{mg}$ $\mathrm{L}^{-1}$ ) (Table 3). Meanwhile, all the treatments significantly affected the level of total antioxidants in 'Lane Late' sweet orange fruit but not in 'Midknight Valencia'. 'Lane Late' fruit treated with SA ( $3 \mathrm{mM}) 1 \mathrm{~min}$ dip resulted in the significantly highest level of antioxidants (569.5 $\mathrm{MM}$ Trolox $\mathrm{L}^{-1}$ ) as compared to the control and all other treatments (Table 3 ).

\section{Individual and total sugars}

All the treatments significantly affected the level of glucose in the juice of 'Lane Late' and 'Midknight Valencia'. In 'Lane Late', all the NO treatments, SA ( $3 \mathrm{mM})$ and MJ $(0.10$ and $0.50 \mathrm{mM}) 1 \mathrm{~min}$ dip, showed a significantly $(P \leq 0.05)$ reduced concentration of glucose in juice as compared to the control (19.3 $\left.\mathrm{g} \mathrm{L}^{-1}\right)$ and all other treatments (Table 4). Moreover, 'Midknight Valencia' fruit fumigated with NO (20 $\left.\mu \mathrm{L} \mathrm{L}^{-1}\right)$ for two $\mathrm{h}$ and $\mathrm{MJ}(0.1$ or $0.50 \mathrm{mM}) 1 \mathrm{~min}$ dip exhibited 
Table 1. Effects of HW alone and combined with TBZ, different concentrations of MJ, SA dips and NO fumigation on hue angle ( $h^{\circ}$ ) and citrus colour index $(\mathrm{CCl})$ in sweet orange cv. "Lane Late" and "Midknight Valencia" following the cold quarantine treatment $\left(1^{\circ} \mathrm{C}\right.$ for $\left.21 \mathrm{~d}\right)$ and $10 \mathrm{~d}$ at simulated shelf-life conditions.

\begin{tabular}{|c|c|c|}
\hline \multicolumn{3}{|c|}{ Fruit colour } \\
\hline \multicolumn{3}{|c|}{ 'Lane Late' } \\
\hline Treatments & $h^{\circ}$ & $\mathrm{CCl}$ \\
\hline Control & $62.0 a$ & $8.1 \mathrm{~b}$ \\
\hline $\mathrm{HW} 50^{\circ} \mathrm{C}$ & $62.1 a$ & $8.0 \mathrm{~b}$ \\
\hline $\operatorname{TBZ}\left(20 \mathrm{mgL}^{-1}\right)+\mathrm{HW}$ & $62.1 \mathrm{a}$ & $8.1 b$ \\
\hline $\mathrm{MJ}(0.10 \mathrm{mM})$ & $60.7 b$ & $8.7 a$ \\
\hline $\mathrm{MJ}(0.25 \mathrm{mM})$ & $61.8 a$ & $8.2 b$ \\
\hline $\mathrm{MJ}(0.50 \mathrm{mM})$ & $61.8 \mathrm{a}$ & $8.2 b$ \\
\hline $\mathrm{SA}(1 \mathrm{mM})$ & $62.2 \mathrm{a}$ & $8.0 \mathrm{~b}$ \\
\hline $\mathrm{SA}(2 \mathrm{mM})$ & $62.5 a$ & $7.9 \mathrm{~b}$ \\
\hline $\mathrm{SA}(3 \mathrm{mM})$ & $62.4 a$ & $7.9 b$ \\
\hline NO $\left(5 \mu L^{-1}\right)$ & $62.6 a$ & $7.9 \mathrm{~b}$ \\
\hline $\mathrm{NO}\left(10 \mu \mathrm{L} \mathrm{L}^{-1}\right)$ & $62.5 a$ & $7.9 \mathrm{~b}$ \\
\hline $\mathrm{NO}\left(20 \mu \mathrm{L} \mathrm{L}^{-1}\right)$ & $62.5 a$ & $7.8 \mathrm{~b}$ \\
\hline \multicolumn{3}{|c|}{ 'Midknight Valencia' } \\
\hline Control & $62.2 a b$ & 8.0 \\
\hline ET $\left(10 \mu L^{-1}\right)$ & $61.7 a b c$ & 8.3 \\
\hline $\mathrm{HW} 50^{\circ} \mathrm{C}$ & $62.2 \mathrm{ab}$ & 8.0 \\
\hline $\operatorname{TBZ}\left(20 \mathrm{mgL}^{-1}\right)+\mathrm{HW}$ & $61.2 \mathrm{c}$ & 8.4 \\
\hline $\mathrm{MJ}(0.10 \mathrm{mM})$ & $61.6 a b c$ & 8.3 \\
\hline $\mathrm{MJ}(0.25 \mathrm{mM})$ & $62.4 a$ & 8.0 \\
\hline $\mathrm{MJ}(0.50 \mathrm{mM})$ & $62.3 a$ & 8.1 \\
\hline $\mathrm{NO}\left(5 \mu \mathrm{L} \mathrm{L}^{-1}\right)$ & $62.0 \mathrm{abc}$ & 8.1 \\
\hline $\mathrm{NO}\left(10 \mu \mathrm{L} \mathrm{L}^{-1}\right)$ & $62.1 \mathrm{ab}$ & 8.2 \\
\hline $\mathrm{NO}\left(20 \mu \mathrm{L} \mathrm{L}^{-1}\right)$ & $61.4 \mathrm{bc}$ & 8.5 \\
\hline
\end{tabular}

Data represent means of 3 replicate samples of 30 units for 'Lane Late' and 'Midknight Valencia'. Mean separation for significant analysis of variance within the columns and rows was tested using Duncan's multiple range test at $(P<0.05)$. Mean followed by the same letter was not significantly different within the columns. HW (hot water) 5-min dip, TBZ (thiabendazole) combined with HW 5 min dip, ET (ethylene) $6 \mathrm{~h}$ fumigation, MJ (methyl jasmonate) one min dip, SA (salicylic acid) one min dip and NO (nitric oxide) fumigation for $2 \mathrm{~h}$.

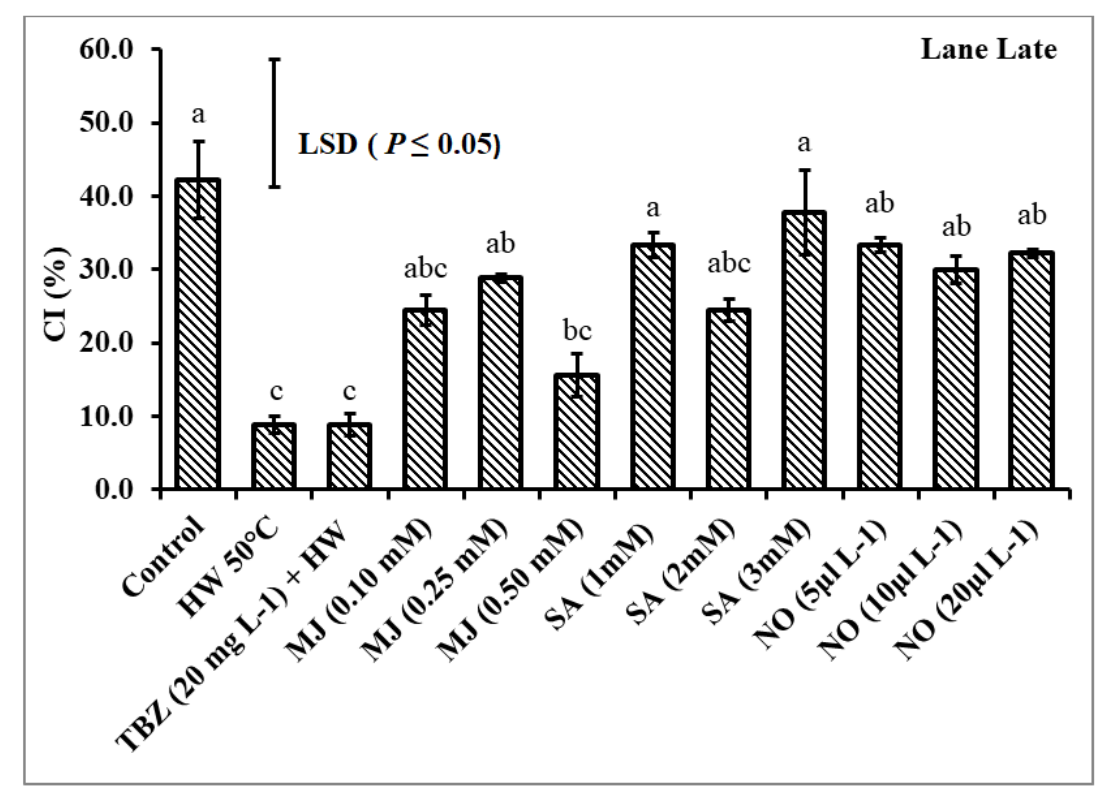

Fig 1. Incidence of $\mathrm{Cl}$ (percentage chill injured fruit) affected by hot water alone and combined with TBZ and different concentrations of MJ, SA dips and fumigation of NO in sweet orange cv. 'Lane Late' following the cold quarantine treatment $\left(1^{\circ} \mathrm{C}\right.$ for $21 \mathrm{~d})$ and $10 \mathrm{~d}$ at simulated shelf-life conditions. Vertical bars represent $\mathrm{SE}, \mathrm{n}=$ three replicates, thirty fruit per replication. Any two means with different lower case letters represent significant differences at $(P \leq 0.05)$. HW (hot water) 5-min dip, TBZ (thiabendazole) combined with HW 5 min dip, MJ (methyl jasmonate) one min dip, SA (salicylic acid) 1 min dip and NO (nitric oxide) fumigation for $2 \mathrm{~h}$. 
Table 2. Effect of HW alone and combined with TBZ, different concentration of MJ, SA dips and fumigation of NO on weight loss (\%) and fruit firmness in sweet orange cv. 'Lane Late' and 'Midknight Valencia' following the cold quarantine treatment $\left(1^{\circ} \mathrm{C}\right.$ for 21 days) and 10 days at simulated shelf-life conditions.

\begin{tabular}{|c|c|c|}
\hline \multicolumn{3}{|c|}{ 'Lane Late' } \\
\hline Treatment & Weight loss (\%) & Firmness (N) \\
\hline Control & $6.0 a b c$ & 262.2 \\
\hline $\mathrm{HW} 50^{\circ} \mathrm{C}$ & $7.6 a b$ & 302.4 \\
\hline TBZ $\left(20 \mathrm{mgL}^{-1}\right)+\mathrm{HW}$ & 7.1abc & 286.7 \\
\hline MJ (0.10 mM) & $6.3 a b c$ & 291.8 \\
\hline MJ (0.25 mM) & 7.6ab & 274.1 \\
\hline MJ (0.50 mM) & 4.3abc & 269.0 \\
\hline $\mathrm{SA}(1 \mathrm{mM})$ & $4.9 \mathrm{bcd}$ & 266.5 \\
\hline $\mathrm{SA}(2 \mathrm{mM})$ & 7.9ab & 272.0 \\
\hline $\mathrm{SA}(3 \mathrm{mM})$ & $5.1 \mathrm{bcd}$ & 284.1 \\
\hline $\mathrm{NO}\left(5 \mu \mathrm{L} \mathrm{L}^{-1}\right)$ & $2.9 \mathrm{~d}$ & 277.4 \\
\hline $\mathrm{NO}\left(10 \mu \mathrm{L} \mathrm{L}^{-1}\right)$ & $8.3 a$ & 253.1 \\
\hline NO $\left(20 \mu L^{-1}\right)$ & $9.0 \mathrm{a}$ & 267.9 \\
\hline \multicolumn{3}{|c|}{ 'Midknight Valencia' } \\
\hline Control & 1.8 & 371.2 \\
\hline ET $\left(10 \mu L^{-1}\right)$ & 1.3 & 358.8 \\
\hline $\mathrm{HW} 50^{\circ} \mathrm{C}$ & 1.4 & 414.4 \\
\hline $\operatorname{TBZ}\left(20 \mathrm{mgL}^{-1}\right)+\mathrm{HW}$ & 1.5 & 380.9 \\
\hline MJ (0.10 mM) & 1.4 & 405.4 \\
\hline MJ (0.25 mM) & 1.5 & 393.1 \\
\hline MJ (0.50 mM) & 1.6 & 394.5 \\
\hline $\mathrm{NO}\left(5 \mu \mathrm{L} \mathrm{L}^{-1}\right)$ & 1.4 & 368.8 \\
\hline $\mathrm{NO}\left(10 \mu \mathrm{L} \mathrm{L}^{-1}\right)$ & 1.4 & 355.9 \\
\hline $\mathrm{NO}\left(20 \mu \mathrm{L} \mathrm{L}^{-1}\right)$ & 1.3 & 336.3 \\
\hline
\end{tabular}

Weight loss data represent means of 3 replicate samples of 90 units for 'Lane Late' and 'Midknight Valencia'. Fruit firmness data represent means of 3 replicates simple of 30 units for both cultivars. Mean separation for significant analysis of variance within the columns and rows was tested using Duncan's multiple range test at $(P<0.05)$. Mean followed by the same letter was not significantly different within the columns. HW (hot water) 5 -min dip, TBZ (thiabendazole) combined with HW 5 min dip, ET (ethylene) $6 \mathrm{~h}$ fumigation, MJ (methyl jasmonate) one min dip, SA (salicylic acid) one different within the columns. HW (hot water) $5-\mathrm{m}$.
min dip and NO (nitric oxide) fumigation for $2 \mathrm{~h}$.

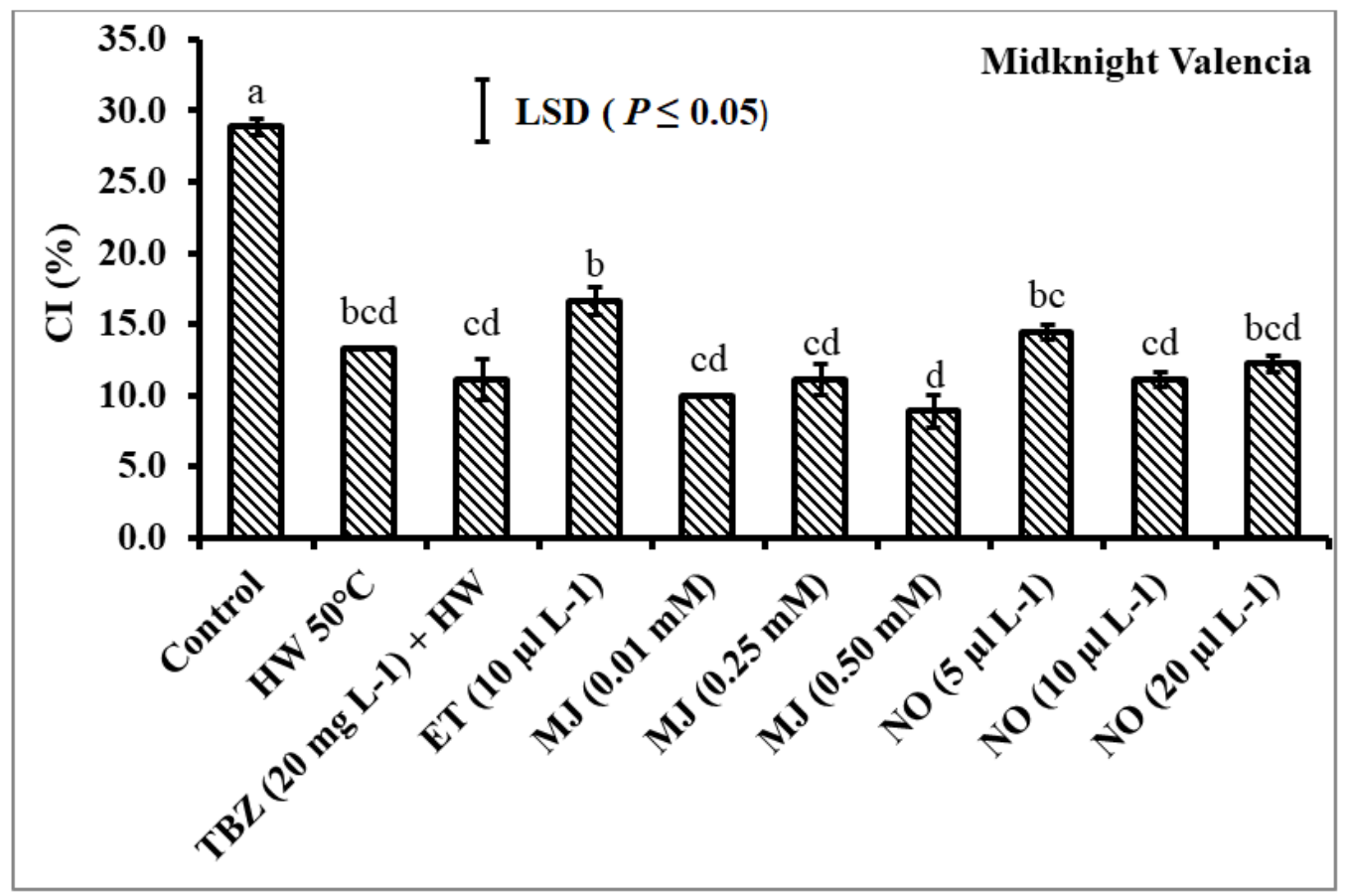

Fig 2. Incidence of $\mathrm{Cl}$ (percentage chill injured fruit) affected by hot water alone and combined with TBZ and different concentrations of MJ, SA dips and fumigation of NO in sweet orange cv. 'Midknight Valencia' following the cold quarantine treatment $\left(1{ }^{\circ} \mathrm{C}\right.$ for $21 \mathrm{~d}$ ) and $10 \mathrm{~d}$ at simulated shelf-life conditions. Vertical bars represent $\mathrm{SE}, \mathrm{n}=$ three replicates, thirty fruit per replication. Vertical bars represent $\mathrm{SE}, \mathrm{n}=$ three replicates, thirty fruit per replication. Any two means with different lower case letters represent significant differences at $(P \leq 0.05)$. HW (hot water) 5-min dip, TBZ (thiabendazole) combined with HW 5 min dip, ET (ethylene) $6 \mathrm{~h}$ fumigation, MJ (methyl jasmonate) one min dip, SA (salicylic acid) 1 min dip and NO (nitric oxide) fumigation for 2 h. 
Table 3. Effect of HW alone and combined with TBZ, different concentrations of MJ, SA dips and fumigation of NO on SSC, TA, SSC/TA ratio, vitamin C and total antioxidants in the juice of sweet orange cv. 'Lane Late' and 'Midknight Valencia' following the cold quarantine treatment $\left(1^{\circ} \mathrm{C}\right.$ for 21 days) and 10 days at simulated shelf-life conditions.

\begin{tabular}{|c|c|c|c|c|c|}
\hline \multirow[b]{2}{*}{ Treatment } & \multicolumn{5}{|c|}{ 'Lane Late' } \\
\hline & SSC (\%) & $\begin{array}{l}\text { TA } \\
(\%)\end{array}$ & $\begin{array}{r}\mathrm{SSC} / \mathrm{TA} \\
\text { ratio }\end{array}$ & Vitamin $C\left(\mathrm{mg} \mathrm{L}^{-1}\right)$ & $\begin{array}{c}\text { Antioxidants } \\
\left(\mu \mathrm{M} \text { Trolox } L^{-1}\right)\end{array}$ \\
\hline Control & $12.1 a$ & 0.61 & 19.7 & 253.2 & $460.3 c d$ \\
\hline $\mathrm{HW} 50^{\circ} \mathrm{C}$ & $11.1 b$ & 0.61 & 18.2 & 261.4 & $476.0 \mathrm{bc}$ \\
\hline $\operatorname{TBZ}\left(20 \mathrm{mgL}^{-1}\right)+\mathrm{HW}$ & $11.4 b$ & 0.59 & 19.3 & 253.6 & $501.7 b$ \\
\hline $\mathrm{MJ}(0.10 \mathrm{mM})$ & $11.4 b$ & 0.63 & 18.2 & 244.1 & $442.6 d$ \\
\hline $\mathrm{MJ}(0.25 \mathrm{mM})$ & $11.0 \mathrm{~b}$ & 0.56 & 19.5 & 255.4 & $478.6 b c$ \\
\hline $\mathrm{MJ}(0.50 \mathrm{mM})$ & $11.6 a b$ & 0.55 & 21.0 & 231.2 & $436.9 d$ \\
\hline $\mathrm{SA}(1 \mathrm{mM})$ & $11.2 \mathrm{~b}$ & 0.60 & 18.7 & 225.1 & $439.5 d$ \\
\hline $\mathrm{SA}(2 \mathrm{mM})$ & $10.4 c$ & 0.58 & 18.0 & 261.8 & $478.8 b c$ \\
\hline $\mathrm{SA}(3 \mathrm{mM})$ & $9.9 c$ & 0.55 & 18.1 & 270.9 & $569.5 a$ \\
\hline $\mathrm{NO}\left(5 \mu \mathrm{L} \mathrm{L}^{-1}\right)$ & $11.3 b$ & 0.59 & 19.2 & 237.2 & $453.7 c d$ \\
\hline $\mathrm{NO}\left(10 \mu \mathrm{L} \mathrm{L}^{-1}\right)$ & $11.3 b$ & 0.56 & 20.1 & 225.6 & $406.7 e$ \\
\hline $\mathrm{NO}\left(20 \mu \mathrm{L} \mathrm{L}^{-1}\right)$ & $11.3 \mathrm{~b}$ & 0.58 & 19.6 & 240.7 & $463.4 \mathrm{~cd}$ \\
\hline \multicolumn{6}{|c|}{ 'Midknight Valencia' } \\
\hline Control & $13.1 a$ & $0.78 c$ & $16.8 \mathrm{a}$ & 295.9abc & 482.3 \\
\hline ET $\left(10 \mu L^{-1}\right)$ & 13.0ab & $0.91 a$ & $14.3 d$ & $324.0 \mathrm{ab}$ & 490.0 \\
\hline $\mathrm{HW} 50^{\circ} \mathrm{C}$ & $12.7 \mathrm{bcd}$ & $0.81 b c$ & $15.7 \mathrm{bc}$ & $244.6 c d$ & 492.5 \\
\hline TBZ $\left(20 \mathrm{mgL}^{-1}\right)+\mathrm{HW}$ & $12.8 \mathrm{abcd}$ & $0.83 b$ & $15.4 \mathrm{c}$ & $215.2 d$ & 507.9 \\
\hline $\mathrm{MJ}(0.10 \mathrm{mM})$ & $12.5 \mathrm{~cd}$ & $0.77 c$ & $16.3 a b$ & $247.6 \mathrm{bcd}$ & 474.6 \\
\hline $\mathrm{MJ}(0.25 \mathrm{mM})$ & $12.7 \mathrm{bcd}$ & $0.92 a$ & $13.8 \mathrm{~d}$ & $222.6 \mathrm{~cd}$ & 454.9 \\
\hline $\mathrm{MJ}(0.50 \mathrm{mM})$ & $12.5 \mathrm{~d}$ & $0.78 c$ & $16.0 \mathrm{abc}$ & $297.2 a b c$ & 466.0 \\
\hline $\mathrm{NO}\left(5 \mu \mathrm{L} \mathrm{L}^{-1}\right)$ & $12.6 \mathrm{~cd}$ & $0.78 c$ & 16.1abc & $295.5 a b c$ & 484.0 \\
\hline $\mathrm{NO}\left(10 \mu \mathrm{L} \mathrm{L}^{-1}\right)$ & 12.9abc & $0.78 c$ & $16.5 a b$ & $359.4 a$ & 485.7 \\
\hline $\mathrm{NO}\left(20 \mu \mathrm{L} \mathrm{L}^{-1}\right)$ & $12.8 \mathrm{abcd}$ & $0.78 c$ & $16.4 a b$ & $213.5 d$ & 465.7 \\
\hline
\end{tabular}

Table 4. Effect of HW alone and combined with TBZ, different concentrations of MJ, SA dips and fumigation of NO on the levels of individual and total sugars in sweet orange cv. 'Lane Late' and 'Midknight Valencia' following the cold quarantine treatment $\left(1^{\circ} \mathrm{C}\right.$ for 21 days) and 10 days at simulated shelf-life conditions.

\begin{tabular}{|c|c|c|c|c|}
\hline \multirow[b]{3}{*}{ Treatment } & \multicolumn{4}{|c|}{ 'Lane Late' } \\
\hline & \multicolumn{4}{|c|}{ Individual and total sugars $\left(\mathrm{gL}^{-1}\right)$} \\
\hline & Glucose & Fructose & Sucrose & Total Sugars \\
\hline Control & $19.3 a$ & $25.4 a$ & $59.8 a$ & $104.5 a$ \\
\hline $\mathrm{HW} 50^{\circ} \mathrm{C}$ & 17.9abcde & $22.8 \mathrm{bc}$ & $50.8 \mathrm{bc}$ & $91.7 \mathrm{bc}$ \\
\hline TBZ $\left(20 \mathrm{mgL}^{-1}\right)+\mathrm{HW}$ & $19.2 \mathrm{ab}$ & $24.5 \mathrm{ab}$ & $52.4 \mathrm{bc}$ & $96.3 b$ \\
\hline $\mathrm{MJ}(0.10 \mathrm{mM})$ & $17.7 \mathrm{cde}$ & $22.7 \mathrm{bc}$ & $51.6 \mathrm{bc}$ & $92.1 b c$ \\
\hline $\mathrm{MJ}(0.25 \mathrm{mM})$ & $18.4 \mathrm{abcd}$ & $23.2 b c$ & $48.9 \mathrm{~cd}$ & $90.7 b c$ \\
\hline $\mathrm{MJ}(0.50 \mathrm{mM})$ & $17.7 \mathrm{cde}$ & $23.2 b c$ & $55.1 \mathrm{ab}$ & $96.1 b$ \\
\hline $\mathrm{SA}(1 \mathrm{mM})$ & $18.7 a b c$ & $23.5 b c$ & $51.4 \mathrm{bc}$ & $93.6 b$ \\
\hline $\mathrm{SA}(2 \mathrm{mM})$ & 17.9abcde & $22.5 c$ & $45.4 d$ & $85.5 c$ \\
\hline $\mathrm{SA}(3 \mathrm{mM})$ & $17.9 b c d e$ & $22.5 c$ & $44.9 d$ & $85.3 c$ \\
\hline $\mathrm{NO}\left(5 \mu \mathrm{L} \mathrm{L}^{-1}\right)$ & $17.5 \mathrm{cde}$ & $22.7 \mathrm{bc}$ & $51.8 \mathrm{bc}$ & $92.1 b c$ \\
\hline $\mathrm{NO}\left(10 \mu \mathrm{L} \mathrm{L}^{-1}\right)$ & $17.0 \mathrm{e}$ & $22.3 c$ & $51.0 \mathrm{bc}$ & $90.4 b c$ \\
\hline NO $\left(20 \mu L^{-1}\right)$ & $17.3 \mathrm{de}$ & $22.6 c$ & $54.6 a b c$ & $94.6 \mathrm{~b}$ \\
\hline \multicolumn{5}{|c|}{ 'Midknight Valencia' } \\
\hline Control & 19.9ab & $26.0 a$ & $53.4 a$ & $99.3 a$ \\
\hline ET $\left(10 \mu L^{-1}\right)$ & $20.1 a$ & $26.1 \mathrm{a}$ & $53.4 a$ & $99.7 a$ \\
\hline $\mathrm{HW} 50^{\circ} \mathrm{C}$ & $18.9 \mathrm{bc}$ & $24.6 \mathrm{bc}$ & $50.8 c$ & $94.4 b c d$ \\
\hline TBZ $\left(20 \mathrm{mgL}^{-1}\right)+\mathrm{HW}$ & $19.2 a b c$ & $25.1 \mathrm{ab}$ & $52.1 b$ & $96.5 b$ \\
\hline $\mathrm{MJ}(0.10 \mathrm{mM})$ & $17.9 d$ & $23.8 \mathrm{c}$ & $52.1 b$ & $93.9 \mathrm{~cd}$ \\
\hline $\mathrm{MJ}(0.25 \mathrm{mM})$ & $19.2 a b c$ & $25.1 a b$ & $51.7 \mathrm{bc}$ & $96.0 b c$ \\
\hline $\mathrm{MJ}(0.50 \mathrm{mM})$ & $18.4 \mathrm{~cd}$ & $24.3 b c$ & $51.1 \mathrm{bc}$ & $93.8 d$ \\
\hline $\mathrm{NO}\left(5 \mu \mathrm{L} \mathrm{L}^{-1}\right)$ & $19.3 a b c$ & $25.2 \mathrm{ab}$ & $50.9 c$ & $95.4 \mathrm{bcd}$ \\
\hline $\mathrm{NO}\left(10 \mu \mathrm{L} \mathrm{L}^{-1}\right)$ & $19.7 a b$ & $26.0 a$ & $54.2 a$ & $100.0 a$ \\
\hline $\mathrm{NO}\left(20 \mu \mathrm{L} \mathrm{L}^{-1}\right)$ & $18.5 \mathrm{~cd}$ & $24.4 b c$ & $51.3 \mathrm{bc}$ & $94.1 \mathrm{~cd}$ \\
\hline
\end{tabular}

Data represent means of 3 replicate samples of 30 units for 'Lane Late' and 'Midknight Valencia'. Mean separation for significant analysis of variance within the columns and rows was tested using Duncan's multiple range test at $(P<0.05)$. Mean followed by the same letter not significantly different within the columns. HW (hot water) 5 -min dip, TBZ (thiabendazole) combined with HW 5 min dip, ET (ethylene) $6 \mathrm{~h}$ fumigation, MJ (methyl jasmonate) one min dip, SA (salicylic acid) one min dip and NO (nitric oxide) fumigation for $2 \mathrm{~h}$. 
Table 5. Effect of HW alone and combined with TBZ, different concentrations of MJ, SA dips and fumigation of NO on the levels of individual and total organic acids in sweet orange cv. 'Lane Late' and 'Midknight Valencia' following the cold quarantine treatment $\left(1^{\circ} \mathrm{C}\right.$ for 21 days) and 10 days at simulated shelf-life conditions.

\begin{tabular}{|c|c|c|c|c|c|c|}
\hline \multirow[b]{3}{*}{ Treatment } & \multicolumn{6}{|c|}{ 'Lane Late' } \\
\hline & \multicolumn{6}{|c|}{ Individual and total organic acids $\left(\mathrm{g} \mathrm{L}^{-1}\right)$} \\
\hline & Citric & Malic & Tartaric & Fumaric & Succinic & $\begin{array}{c}\text { Total } \\
\text { organic } \\
\text { acids }\end{array}$ \\
\hline Control & $2.1 \mathrm{abc}$ & 0.68 & 0.63 & 0.41 & 0.76 & 4.6 \\
\hline $\mathrm{HW} 50^{\circ} \mathrm{C}$ & $2.3 a$ & 0.59 & 0.63 & 0.39 & 0.79 & 4.7 \\
\hline $\mathrm{TBZ}\left(20 \mathrm{mgL}^{-1}\right)+\mathrm{HW}$ & $2.0 \mathrm{abc}$ & 0.53 & 0.64 & 0.39 & 0.83 & 4.4 \\
\hline MJ (0.10 mM) & $1.7 \mathrm{bc}$ & 0.61 & 0.63 & 0.39 & 0.69 & 4.1 \\
\hline $\mathrm{MJ}(0.25 \mathrm{mM})$ & $1.6 \mathrm{c}$ & 0.49 & 0.63 & 0.37 & 0.90 & 4.0 \\
\hline $\mathrm{MJ}(0.50 \mathrm{mM})$ & $1.7 \mathrm{bc}$ & 0.71 & 0.62 & 0.42 & 0.77 & 4.2 \\
\hline $\mathrm{SA}(1 \mathrm{mM})$ & $2.2 a b$ & 0.61 & 0.63 & 0.39 & 0.72 & 4.6 \\
\hline $\mathrm{SA}(2 \mathrm{mM})$ & $1.8 \mathrm{abc}$ & 0.49 & 0.62 & 0.36 & 0.82 & 4.6 \\
\hline $\mathrm{SA}(3 \mathrm{mM})$ & $2.1 \mathrm{abc}$ & 0.48 & 0.63 & 0.36 & 0.80 & 4.1 \\
\hline $\mathrm{NO}\left(5 \mu \mathrm{L} \mathrm{L}^{-1}\right)$ & $1.7 \mathrm{bc}$ & 0.57 & 0.63 & 0.37 & 0.79 & 4.1 \\
\hline NO $\left(10 \mu L^{-1}\right)$ & $1.7 \mathrm{bc}$ & 0.53 & 0.62 & 0.38 & 0.73 & 4.0 \\
\hline $\mathrm{NO}\left(20 \mu \mathrm{L} \mathrm{L}^{-1}\right)$ & $1.8 \mathrm{abc}$ & 0.51 & 0.63 & 0.37 & 0.75 & 4.1 \\
\hline \multicolumn{7}{|c|}{ 'Midknight Valencia' } \\
\hline Control & 1.8 & 0.51 & 0.63 & 0.36 & 0.64 & 4.0 \\
\hline $\mathrm{ET}\left(10 \mu \mathrm{L} \mathrm{L}^{-1}\right)$ & 2.7 & 0.76 & 0.63 & 0.43 & 0.67 & 5.2 \\
\hline $\mathrm{HW} 50^{\circ} \mathrm{C}$ & 2.1 & 0.58 & 0.63 & 0.39 & 0.61 & 4.3 \\
\hline $\mathrm{TBZ}\left(20 \mathrm{mgL}^{-1}\right)+\mathrm{HW}$ & 2.7 & 0.75 & 0.63 & 0.43 & 0.63 & 5.1 \\
\hline MJ (0.10 mM) & 2.1 & 0.76 & 0.63 & 0.42 & 0.66 & 4.5 \\
\hline $\mathrm{MJ}(0.25 \mathrm{mM})$ & 2.2 & 0.82 & 0.62 & 0.39 & 0.66 & 4.3 \\
\hline $\mathrm{MJ}(0.50 \mathrm{mM})$ & 2.0 & 0.60 & 0.62 & 0.44 & 0.64 & 4.7 \\
\hline $\mathrm{NO}\left(5 \mu \mathrm{L} \mathrm{L}^{-1}\right)$ & 2.3 & 0.64 & 0.63 & 0.40 & 0.70 & 4.7 \\
\hline $\mathrm{NO}\left(10 \mu \mathrm{L} \mathrm{L}^{-1}\right)$ & 2.3 & 0.80 & 0.63 & 0.43 & 0.67 & 4.8 \\
\hline $\mathrm{NO}\left(20 \mu \mathrm{L} \mathrm{L}^{-1}\right)$ & 2.1 & 0.52 & 0.64 & 0.37 & 0.66 & 4.3 \\
\hline
\end{tabular}

Data represent means of 3 replicate samples of 30 units for 'Lane Late' and 'Midknight Valencia'. Mean separation for significant analysis of variance within the columns and rows was tested using Duncan's multiple range test at $(P<0.05)$. Mean followed by the same letters or no letters was not significantly different within the columns. HW (hot water) 5 -min dip, TBZ (thiabendazole) combined with HW 5 min dip, ET (ethylene) 6 h fumigation, MJ (methyl jasmonate) one min dip, SA (salicylic acid) one min dip and NO (nitric oxide) fumigation for $2 \mathrm{~h}$.

a reduced level of glucose in the juice as compared to the control and all other treatments. In 'Lane Late', all the treatments except TBZ $\left(20 \mathrm{mg} \mathrm{L}^{-1}\right)$ combined with HWD 5 min dip show significantly reduced concentrations of fructose in the juice as compared to the control $\left(25.4 \mathrm{~g} \mathrm{~L}^{-1}\right)$. On the other hand, in 'Midknight Valencia' HWD alone for 5 $\mathrm{min}, \mathrm{MJ}(0.1$ and $0.50 \mathrm{mM}) 1 \mathrm{~min}$ dip, and NO $\left(20 \mu \mathrm{L} \mathrm{L}^{-1}\right)$ two $\mathrm{h}$ fumigation resulted in significantly reduced levels of fructose in the juice as compared to the control $\left(26.0 \mathrm{~g} \mathrm{~L}^{-1}\right)$ and all other treatments (Table 4). The concentrations of sucrose in the juice of 'Lane Late' were significantly reduced by all treatments except MJ $(0.50 \mathrm{mM}) 1 \mathrm{~min}$ dip and NO $(20$ $\left.\mu \mathrm{L} \mathrm{L}^{-1}\right) 2 \mathrm{~h}$ fumigation as compared to the control $\left(59.8 \mathrm{~g} \mathrm{~L}^{-1}\right)$. In 'Midknight Valencia', all the treatments except ethylene $\left(10 \mu \mathrm{L} \mathrm{L}^{-1}\right)$ six h fumigation and NO $\left(10 \mu \mathrm{L} \mathrm{L}^{-1}\right) 2 \mathrm{~h}$ fumigation exhibited reduced concentrations of sucrose in the juice as compared to the control $\left(53.4 \mathrm{~g} \mathrm{~L}^{-1}\right)$. The concentrations of total sugars in the juice of 'Lane Late' were significantly reduced by all the treatments as compared to the control (104.5 $\left.\mathrm{g} \mathrm{L}^{-1}\right)$. Meanwhile, in 'Midknight Valencia', the concentrations of total sugars in the juice were significantly reduced with all the treatments except ethylene $\left(10 \mu \mathrm{L} \mathrm{L}^{-1}\right)$ six $\mathrm{h}$ fumigation and NO $\left(10 \mu \mathrm{L} \mathrm{L} \mathrm{L}^{-1}\right) 2 \mathrm{~h}$ fumigation as compared to the control $\left(99.3 \mathrm{~g} \mathrm{~L}^{-1}\right)$.

\section{Individual and total organic acids}

Amongst various organic acids, citric, malic, tartaric, fumaric and succinic acid were identified and quantified in the juice of both cultivars (Table 5). The concentrations of all individual and total organic acids in the juice of 'Lane Late' and 'Midknight Valencia' sweet orange fruit (except citric acid in 'Lane Late') were not significantly affected by any of the treatments applied (Table 5). The concentration of citric acid in the juice of 'Lane Late' was significantly reduced when the fruit were treated with $\mathrm{MJ}(0.1,0.25$ or $0.50 \mathrm{mM})$ $1 \mathrm{~min}$ dip and NO (5 and $10 \mu \mathrm{L} \mathrm{L}^{-1}$ ) two $\mathrm{h}$ fumigation as compared to the control and all other treatments.

\section{Discussion}

Postharvest disinfection of citrus fruit by employing quarantine treatments is mandatory to meet the requirements outlined by importing countries. During the past few decades, heat treatments have been used to control postharvest fungal disease and insect disinfestation (Barkai-Golan and Phillips 1991). The heat treatment can also be commercially used to enhance chilling tolerance during cold storage (Wang, 1993). The symptoms of $\mathrm{Cl}$ on citrus fruit is expressed as rind staining, pitting, red blotches, scalding, watery breakdown, sunken tissues, damage to the styler end of lemons and necrosis on the flavedo (Reuther et al., 1989).

The experimental results indicate that HWD at $50{ }^{\circ} \mathrm{C}$ for 5 min is effective in reducing $\mathrm{Cl}$ caused by cold quarantine treatment $\left(1^{\circ} \mathrm{C}\right.$ for $\left.21 \mathrm{~d}\right)$ in sweet orange cv. 'Lane Late' and 'Midknight Valencia'. Possibly, HWD treatment might enhance the natural defence system of the fruit against $\mathrm{Cl}$ by changing the arrangement, morphology and assembly of 
epicuticular wax, known to play a role in $\mathrm{Cl}$ development (McDonald et al., 1993). Secondly, heat treatment may alter the enzyme system responsible for tissue degradation during the development of $\mathrm{Cl}$ (Parkin et al., 1989; Martinez-Tellez and Lafunte, 1997). Thirdly, HWD treatment probably enhanced chilling tolerance by the upregulation of POX, CAT and total phenolic content (TP) as reported earlier in 'Valencia' and 'Navel' oranges (Bassal and El- Hamahmy 2011). Previously, HWD (2-3 $\mathrm{min}$ ) has been reported to enhance the chilling tolerance in 'Valencia' sweet orange fruit (Wild and Hood, 1989) and HWD (53 o C for 6 min and 48 으 for $12 \mathrm{~min}$ ) also reduced $\mathrm{Cl}$ incidence in 'Satsuma' mandarins (Ghasemnezhad et al., 2008).

The experimental results exhibit that TBZ $\left(20 \mathrm{mg} \mathrm{L}^{-1}\right)$ combined with hot water $(\mathrm{HW})\left(50^{\circ} \mathrm{C}\right.$ for $\left.5 \mathrm{~min}\right)$ dip treatment significantly reduced $\mathrm{Cl}$ in 'Lane Late' and 'Midknight Valencia' sweet orange. Presently, the exact mode of action of TBZ in enhancing chilling tolerance in sweet orange fruit is unclear. However, it may be argued that TBZ may have induced chilling tolerance by acting indirectly to suppress latent infections that might develop due to low-temperature storage as reported earlier in grapefruit, as result weaken fruit resistance to $\mathrm{Cl}$ (SchiffmanNadel et al., 1972). Regarding the efficacy of TBZ in controlling $\mathrm{Cl}$, it has been reported that due to increased fungicide concentrations and deposits in fruit; its physiological effect has been attributed to a decreased rate of peel senescence (Schiffman-Nadel et al., 1972). It has also been speculated that the HW fungicide treatment enriched infiltration of the fungicide through the epicuticular wax (Hordijk et al., 2013). The effectiveness of TBZ with HW to reduce $\mathrm{Cl}$ in various citrus fruits has been reported in 'Marsh' and 'Redblush' grapefruit (Citrus paradisi Macf.) (McDonald et al., 1991), 'Tarocco' oranges (Schirra and Mulas, 1995) and 'Valencia' oranges (Wild and Hood, 1989). The synergistic effect of TBZ with $\mathrm{HW}$ on reducing $\mathrm{Cl}$ in fruits has also been previously reported by Hordijk et al. (2013). MJ $(0.5 \mathrm{mM})$ 1-min dip treatment reduced $\mathrm{Cl}$ in both cultivars. However, MJ (0.1 or 0.25 ) treatments induced chilling tolerance only in 'Midknight Valencia'. Possibly, MJ has reduced $\mathrm{Cl}$ by the activation of defence mechanisms, such as heat shock proteins (HSPs) and phenolic compounds (Meir et al., 1996; Meng et al., 2009). MJ has also been reported to stimulate the build-up of HSPs which reduced chilling injury in tomato fruit (Ding et al., 2002). Meir et al. (1996) suggested that MJ probably acts together with single transduction cascade of the chemical changes involved in the reduction of $\mathrm{Cl}$. Previously, $\mathrm{MJ}$ has been applied to control $\mathrm{Cl}$ in many fruits such as guava, tomato, papaya, mango and pomegranate (González-Aguilar et al., 2004; Ding et al., 2002; Mirdehghan and Ghotbi, 2014).

All NO $\left(5,10\right.$ or $\left.20 \mu \mathrm{L} \mathrm{L}^{-1}\right)$ fumigation treatments for two $\mathrm{h}$ showed significantly reduced $\mathrm{Cl}$ only in 'Midknight Valencia' not 'Lane Late' fruit. The mode of action through which NO induces chilling tolerance in citrus fruit is yet to be explored. Possibly, NO fumigation may have protected the membrane from damage through the reduction of reactive oxygen species (ROS) and enhanced levels of antioxidants in 'Midknight Valencia' sweet orange. Earlier, Zhu et al. (2008) reported that treatments with $\left(1 \mu \mathrm{mol} \mathrm{L}^{-1}\right)$ NO aqueous solution could protect kiwi fruit from oxidative damage caused by ROS through an enhanced activity of antioxidant enzymes. It may also be argued that endogenous NO production plays an important role in alleviating chilling injury by affecting the antioxidant defence system as reported earlier by Xu et al. (2012).

Fumigation with NO $\left(5 \mu \mathrm{L} \mathrm{L}^{-1}\right)$ exhibited reduced $(2.9 \%)$ water loss in 'Lane Late' but not in 'Midknight Valencia' after cold quarantine treatment $\left(1^{\circ} \mathrm{C}\right.$ for $\left.21 \mathrm{~d}\right)$, which may be ascribed to the genetic difference between two cultivars. Possibly, the reduced water loss in horticultural commodities with NO treatment may be ascribed to a reduced transpiration rate as reported earlier (Ku et al., 2000).

In 'Lane Late' all the treatments except MJ (0.01 mM) showed significantly reduced SSC (\%) and enhanced $\mathrm{CCl}$ as compared to the control but not in 'Midknight Valencia'. Previously, an increased SSC (\%) in 'Tommy Atkin' MJ treated mangoes has been reported (Gonzalez-Anguilar et al. 2000). Fruit firmness was not significantly affected by any of the treatments in both the cultivars. Significantly reduced total sugars were recorded in both cultivars except NO and ET (10 $\mu \mathrm{L} \mathrm{L}^{-1}$ ) in 'Midknight Valencia'. Contrarily, Deng et al. (2013) reported earlier that pre-harvest treatment with $(50 \mu \mathrm{M})$ SNP efficiently maintained a higher content of sucrose and lower content of glucose in Golden Delicious apples. Furthermore, Li et al. (2014) claimed the levels of glucose; fructose and sucrose during fruit ripening of papaya fruit were significantly influenced by NO fumigation. It appears that the effects of NO fumigation are not only limited to SSC but also influence post-harvest sugar metabolism.

\section{Materials and methods}

\section{Plant materials}

Mature fruit of cv. 'Lane Late' and 'Midknight Valencia' (Citrus sinensis (L.) Osbeck) were harvested randomly around the tree canopy from a commercial orchard at Moora (30 35' S $\left./ 115^{\circ} 55^{\prime} \mathrm{E}\right)$, Western Australia during 2015. 'Lane Late' and 'Midknight Valencia' sweet orange trees (seven and nine years old respectively) earlier grafted on Carrizo citrange (Citrus sinensis (L.) Osbeck $\times$ Poncirus trifoliata Raf.) rootstock. The trees were spaced at $2.7 \times 7.5$ $\mathrm{m}$, row direction north-south. Following the harvest, the fruit were brought to the Horticulture Research Laboratory, Curtin University, Perth, WA. The fruit used in this experiment were free from symptoms of diseases, pest damage, blemishes and physical injuries.

\section{Experiment 1: Effects of HW, MJ, TBZ and NO treatments on} $\mathrm{Cl}$ incidence and fruit quality in "Lane Late" sweet orange

'Lane Late' sweet orange fruit were dipped in $\mathrm{HW}\left(50^{\circ} \mathrm{C}\right.$ for 5 $\mathrm{min})$ alone and $\mathrm{HW}$ combined with TBZ $\left(20 \mathrm{mg} \mathrm{L}^{-1}\right), \mathrm{MJ}(0.10$, 0.25 or $0.50 \mathrm{mM})$ and $\mathrm{SA}(1,2$ or $3 \mathrm{mM}) 1 \mathrm{~min}$ dip and untreated fruit were kept as control. Fruit were fumigated with different concentrations of NO $\left(5,10\right.$ or $\left.20 \mu \mathrm{L} \mathrm{L}^{-1}\right)$ for 2 $\mathrm{h}$ in a $60 \mathrm{~L}$ container. Following the treatments, the fruit were dried for $6 \mathrm{~h}$ at room temperature $\left(20 \pm 1{ }^{\circ} \mathrm{C}\right)$ and relative humidity $(60 \pm 5 \%)$. The fruit were transferred to the cold storage $\left(1^{\circ} \mathrm{C}\right)$ for 21 days with $(85-90 \%)$ relative humidity. The experiment was laid out by following completely randomised design and included three replications. Each replication included 30 fruit. The observations recorded were incidence of chilling injury (\%), colour coordinates $\left[\left(h^{\circ}\right.\right.$ and citrus colour index $\left.(\mathrm{CCl})\right]$, percentage weight loss, fruit firmness, soluble solids 
concentration (SSC), titratable acidity (TA), SSC: TA, vitamin $\mathrm{C}$ and total antioxidants, individual and total sugars and organic acids, were determined from the fruit stored at 1 o $C$ for 21 days and followed by 10 days in simulated shelf conditions $\left(21 \pm 1^{\circ} \mathrm{C}\right)$. However, the fruit percentage weight loss was recorded only at 22 days after cold storage.

Experiment 2: Effects of HW, MJ, TBZ, ET and NO treatments on $\mathrm{Cl}$ incidence and fruit quality in 'Midknight Valencia' sweet orange

In this experiment, the 'Midknight Valencia' sweet orange fruit were treated with $\mathrm{HW}\left(50^{\circ} \mathrm{C}\right.$ for $\left.5 \mathrm{~min}\right)$ dip alone and combined with TBZ $\left(20 \mathrm{mg} \mathrm{L}^{-1}\right)$, MJ $(0.10,0.25$ or $0.50 \mathrm{mM}) 1$ min dip as well as fruit fumigated with different concentrations of $\mathrm{NO}\left(5,10\right.$ or $\left.20 \mathrm{\mu L} \mathrm{L}^{-1}\right)$ for $2 \mathrm{hrs}$ and ethylene (ET) $\left(10 \mu \mathrm{L} \mathrm{L}^{-1}\right)$ for $6 \mathrm{~h}$ in $60 \mathrm{~L}$ containers. The fruit were dried for $6 \mathrm{~h}$ at room temperature $\left(20 \pm 1{ }^{\circ} \mathrm{C}\right)$ and relative humidity $(60 \pm 5 \%)$ and then transferred to the cold storage $\left(1^{\circ} \mathrm{C}\right)$ for 21 days with $(85-90 \%)$ relative humidity. The experiment was designed by following completely randomised with one factor including treatments with three replications. Each replication has 30 fruit. All the observations mentioned in Experiment 1 were also recorded in this experiment.

\section{Observations recorded}

\section{Chilling Injury incidence (\%)}

All the fruit were visually examined for the symptoms of $\mathrm{Cl}$ following 90 days cold storage and 10 days simulated shelf conditions $\left(21 \pm 1^{\circ} \mathrm{C}\right)$. Chill injured fruit were counted from the total fruit in each replication. Percentage chilling injury incidence (as percentage of chill injured fruit) was calculated using the following formula:

Chilling injury incidence $(\%)=$ Number of chill injured fruit $\times 100$ Total number of fruit

\section{Determination of the fruit colour}

Citrus rind colour was recorded by using colour flex EZ $\left(45^{\circ} / 0^{\circ}\right.$ design) spectrocolorimeter (Hunter Lab, Hunter Associates Laboratory Inc., Reston, VA, USA) on three positions around the equatorial plane of the fruit. Ten fruit were randomly selected from each replication. While using the head $15 \mathrm{~mm}$ diameter the colour coordinates ( $\mathrm{L}^{*}, \mathrm{a}^{*}$ and $\left.\mathrm{b}^{*}\right)$ values define a uniform three-dimensional colour space, where $L^{*}$ is the vertical axis and describes the lightness of the fruit colour ( 0 to 100 , black to white) and $a^{*}$ and $b^{*}$ are the horizontal axis defining the redness $\left(+a^{*}\right)$ or greenness ($\left.a^{*}\right)$, and yellow $\left(+b^{*}\right)$ or blue $\left(-b^{*}\right)$, respectively. For colour explanation, red was an angle of $0^{\circ}$ to $360^{\circ}$, yellow at $90^{\circ}$, green at $180^{\circ}$, and blue at $270^{\circ}$. The hue angle $\left(h^{\circ}\right)$ value was calculated as $h^{\circ}=\tan ^{-1} b^{*} / a^{*}$ McGuire (1992). Citrus colour index $(\mathrm{CCl})$ was calculated by using the following formula reported by Jiménez -Cuesta et al. (1981):

$\mathrm{CCI}=(1000 . \mathrm{a}) / \mathrm{Lxb}$

\section{Determination of loss of fruit weight}

The weight of the fruit at the commencement of storage (initial fruit weight) and following the 22 days cold storage (final fruit weight) was recorded by using a digital weighing balance. Fruit weight loss was calculated using the following formula and expressed as percent:

Weight loss $(\%)=\underline{\text { (Initial weight }- \text { Final weight }) \times 100}$

\section{Fruit firmness}

$$
\text { Initial weight }
$$

Fruit firmness was determined using a texture profile analyser (TPA Plus, AMETEK Lloyd Instruments Ltd, Fareham, UK) interfaced with Nexygen 4.6 software by employing a previously detailed method by Hussain (2014). Fruit firmness was expressed in newtons $(\mathrm{N})$.

\section{Soluble solids concentration (SSC) and Titratable acidity} (TA)

A digital refractometer (Atago-Palette PR 101, Atago CO. Ltd, Itabashi-Ku, and Tokyo, Japan) was used to estimate SSC in the fresh juice of 'Midknight Valencia' and 'Lane Late'. SSC was expressed as a percentage. The juice was titrated against $0.1 \mathrm{~N} \mathrm{NaOH}$ to a pink colour end point. Phenolphthalein (2-3 drops) was used as an indicator. TA was calculated as percentage equivalent of citric acid.

\section{Determination of sugars and organic acids}

The levels of individual sugars and organic acids in the juice of Midknight' Valencia' (ten fruit) and 'Lane Late' ( ten fruit) were determined by following the method including conditions of analysis reported (Hussain, 2014) by using reverse-phase high-performance liquid chromatography system (RP-HPLC; Waters, Milford, MA, USA) fitted with refractive index detector (sugars) and dual wavelength UV detector (organic acids). All the individual sugars and organic acids were expressed as $\left(\mathrm{g} \mathrm{L}^{-1}\right)$.

\section{Determination of vitamin C and total antioxidants}

Ten randomly selected fruit from each cultivar were used to extract the juice, which was used for the determination of vitamin C and total antioxidants by using the method reported earlier by Hussain, (2014) and Brand-Williams et al. (1995) respectively, using a UV/VIS spectrometer (Jenway spectrophotometer Model 6405, Dunmow, Essex, UK). The standard curve of L-ascorbic acid was used to calculate vitamin $\mathrm{C}$ concentration in the juice and expressed as (mg L $\left.{ }^{1}\right)$ of fresh juice. However, standard curve of 6-hydroxy-2, 5, 7, 8-tetramethylchromane-2-carboxylic acid (Trolox) was used to calculate total antioxidant and expressed as $\mu \mathrm{M}$ Trolox equivalent antioxidant activity (TEAC) $\left(\mathrm{L}^{-1}\right)$ FJ basis.

\section{Statistical analysis}

The experimental data were subjected to one-way analysis of variance (ANOVA) using GenStat $14^{\text {th }}$ edition (release 14.1; Lawes Agricultural Trust, Rothamsted Experimental Station, Rothamsted, UK). The influences of treatments on different variables were evaluated by ANOVA. The least significant differences (LSD) were tested following the Duncan multiple range test method at probability $(P \leq 0.05)$.

\section{Conclusion}

HW dip $\left(50^{\circ} \mathrm{C}\right.$ for $\left.5 \mathrm{~min}\right)$ alone or combined with thiabendazole $\left(20 \mathrm{mg} \mathrm{L}^{-1}\right)$ or $\mathrm{MJ}(0.05 \mathrm{mM}) 1 \mathrm{~min}$ dip were 
effective in mitigating chilling injury in 'Lane Late' and 'Midknight Valencia' caused during cold quarantine treatment $\left(1^{\circ} \mathrm{C}\right.$ for $\left.21 \mathrm{~d}\right)$. NO $\left(5 \mu \mathrm{L} \mathrm{L}^{-1}\right)$ fumigation for $2 \mathrm{~h}$ significantly reduces percentage weight loss in 'Lane Late' only. MJ $(0.1 \mathrm{mM})$ dip treatment significantly enhanced $\mathrm{CCl}$ only in 'Lane Late'.

\section{Acknowledgements}

Muneer Rehman thankful to the Australian Centre for International Agricultural Research (ACIAR) for awarding the John Allwright Fellowship during his PhD studies. We greatly appreciate Mr Shane Kay, Moora Citrus for providing sweet orange fruit samples used in both experiments. We thank Ms Susan Petersen for her technical support. We also thank Ms Robyn for the proofreading the manuscript.

\section{References}

Barkai-Golan R, Phillips DJ (1991) Postharvest heat treatment of fresh fruits and vegetables for decay control. Plant Dis. 75(11): 1085-1089.

Bassal M, El-Hamahmy M (2011) Hot water dip and preconditioning treatments to reduce chilling injury and maintain the postharvest quality of 'Navel' and 'Valencia' oranges during cold quarantine. Postharvest Biol Technol. 60(3): 186-191.

Brand-Williams W, Cuvelier ME, Berset CLWT (1995) Use of a free radical method to evaluate antioxidant activity. LWTFood Sci Technol. 28(1): 25-30.

Cao S, Zheng Y, Wang K, Jin P, Rui H (2009) Methyl jasmonate reduces chilling injury and enhances antioxidant enzyme activity in post-harvest loquat fruit. Food Chem. 115(4): 1458-1463.

De Lima CPF, Jessup AJ, Cruickshank L, Walsh CJ, Mansfield ER (2007) Cold disinfestation of citrus (Citrus spp.) for Mediterranean fruit fly (Ceratitis capitata) and Queensland fruit fly (Bactrocera tryoni) (Diptera: Tephritidae). New Zealand J Crop Hortic Sci. 35(1): 39-50.

Deng L, Pan X, Chen L, Shen L, Sheng J (2013) Effects of preharvest nitric oxide treatment on ethylene biosynthesis and soluble sugars metabolism in 'Golden Delicious' apples. Postharvest Biol Technol. 84: 9-15.

Ding CK, Wang C, Gross KC, Smith DL (2002) Jasmonate and salicylate induce the expression of pathogenesis-relatedprotein genes and increase resistance to chilling injury in tomato fruit. Planta. 214(6): 895-901.

Ghasemnezhad M, Marsh K, Shilton R, Babalar M, Woolf A (2008) Effect of hot water treatments on chilling injury and heat damage in 'Satsuma' mandarins: Antioxidant enzymes and vacuolar ATPase, and pyrophosphatase. Postharvest Biol Technol. 48(3): 364-371.

Ghorbani B, Pakkish Z, Khezri M (2017) Nitric oxide increases antioxidant enzyme activity and reduces chilling injury in orange fruit during storage. New Zealand J Crop Hortic Sci. DOI: 10.1080/01140671.2017.1345764.

Gonzalez-Aguilar GA, Fortiz J, Cruz R, Baez R, Wang CY (2000) Methyl jasmonate reduces chilling injury and maintains the postharvest quality of mango fruit. J Agric Food Chem. 48(2): 515-519.

Gonzalez-Aguilar GA, Tiznado-Hernandez ME, ZavaletaGatica R, Martınez-Téllez MA (2004) Methyl jasmonate treatments reduce chilling injury and activate the defence response of guava fruits. Biochem Biophys Res Commun. 313(3): 694-701.

Hordijk J, Cronjé PJR, Opara U L (2013) Postharvest application of Thiabendazole reduces chilling injury of citrus fruit. Acta Hortic. 1007: 119-125.

Hussain Z (2014) Role of polyamines and ethylene in creasing of sweet orange fruit. PhD Thesis, Department of Environment and Agriculture, Curtin University of Technology, Western Australia.

Jiménez-Cuesta M, Cuquerella J, Martinez-Javaga JM (1981) Determination of a colour index for citrus fruit degreening. Proc $4^{\text {th }}$ International Citrus Congress, Tokyo, Japan, 9-12 November 1981.

Ku VV, Wills RB, Leshem YAY. (2000) Use of nitric oxide to reduce postharvest water loss from horticultural produce. J Hortic Sci Biotechnol. 75(3): 268-270.

Li XP, Wu B, Guo Q, Wang JD, Zhang P, Chen WX (2014) Effects of nitric oxide on postharvest quality and soluble sugar content in papaya fruit during ripening. J Food Process Preserve. 38(1): 591-599.

Martinez-Tellez MA, Lafuente MT (1997) Effect of hightemperature conditioning on ethylene, phenylalanine ammonia-lyase, peroxidase and polyphenol oxidase activities in flavedo of chilled 'Fortune' mandarin fruit. J Plant Physiol. 150(6): 674-678.

McDonald RE, McCollum TG, Nordby HE (1993) Temperature conditioning and surface treatments of grapefruit affect the expression of chilling injury and gas diffusion. J Amer Soc Hortic Sci. 118(4): 490-496.

McDonald RE, Miller WR, McCollum TG, Brown GE (1991) Thiabendazole and imazalil applied at $53^{\circ} \mathrm{C}$ reduce chilling injury and decay of grapefruit. HortSci. 26(4): 397-399.

McDonald RE, Nordby HE, McCollum TG (1993) Epicuticular wax morphology and composition are related to grapefruit chilling injury. HortSci. 28(4): 311-312.

McGuire RG (1992) Reporting of objective colour measurements. HortSci. 27(12): 1254-1255.

Meir S, Philosoph-Hadas S, Lurie S, Droby S, Akerman M, Zauberman G, Fuchs Y. (1996) Reduction of chilling injury in stored avocado, grapefruit, and bell pepper by methyl jasmonate. Can J Bot. 74(6): 870-874.

Meng X, Han J, Wang Q, Tian S (2009) Changes in physiology and quality of peach fruits treated by methyl jasmonate under low-temperature stress. Food Chem. 114(3): 10281035.

Mirdehghan S, Ghotbi F (2014) Effects of salicylic acid, jasmonic acid, and calcium chloride on reducing chilling injury of pomegranate (Punica granatum L.) fruit. J Agric Sci Technol. 16(1): 163-173.

Nilprapruck P, Pradisthakarn N, Authanithee F, Keebjan P (2013) Effect of exogenous methyl jasmonate on chilling injury and quality of pineapple (Ananas comosus L.) cv. Pattavia. Silpakorn Univ Sci Technol J. 2(2): 33-42.

Palma A, D'Aquino S, Vanadia S, Angioni A, Schirra M (2013) Cold quarantine responses of 'Tarocco' oranges to short hot water and thiabendazole postharvest dip treatments. Postharvest Biol Technol. 78: 24-33.

Parkin KL, Marangoni A, Jackman RL, Yada RY, Stanley DW (1989) Chilling injury. A review of possible mechanisms. J Food Biochem. 13(2): 127-153.

Powell MR (2003) Modelling the response of the Mediterranean fruit fly (Diptera: Tephritidae) to cold treatment. J Econ Entomol. 96(2): 300-310. 
Reuther W, Calavan E, Carman G (1989) The Citrus Industry, v. 5. Postharvest disorders and diseases. The University of California, Division of Agricultural Sciences, Berkley, USA.

Schiffmann-Nadel M, Chalutz E, Waks J, Lattar FS (1972) Reduction of pitting of grapefruit by thiabendazole during long-term cold storage. HortSci. 7: 394-395.

Schirra M, Mulas M (1995) Improving storability of 'Tarocco' oranges by postharvest hot-dip fungicide treatments. Postharvest Biol Technol. 6(1-2): 129-138.

Schirra M, Mulas M, Fadda A, Cauli E (2004) Cold quarantine responses of blood oranges to postharvest hot water and hot air treatments. Postharvest Biol Technol. 31(2): 191200.

Sharples RO (1990) Future directions for horticultural postharvest technology. Postharvest New Inform. 1(3): 191-194.

Siboza XI, Bertling I (2013) The effects of methyl jasmonate and salicylic acid on suppressing the production of reactive oxygen species and increasing chilling tolerance in 'Eureka'lemon [Citrus limon (L.) Burm. F.]. J Horti Sci Biotechnol. 88(3): 269-276.

Siboza XI, Bertling I, Odindo AO (2014) Salicylic acid and methyl jasmonate improve chilling tolerance in cold-stored lemon fruit (Citrus limon). J Plant Physiol. 171(18): 17221731.

Singh SP, Singh Z, Swinny EE (2009) Postharvest nitric oxide fumigation delays fruit ripening and alleviates chilling injury during cold storage of Japanese plums (Prunus salicina Lindell). Postharvest Biol Technol. 53(3): 101-108.

United States Department of Agriculture (2017) Citrus World Markets and Trade. Retrieved from https://apps.fas.usda.gov/psdonline/circulars/citrus.pdf
United States Department of Agriculture Animal and Plant Protection Services. (1976) Plant protection and quarantine treatment Manual. Revised Apr. 1985. Washington, DC.

Wang CY (1993) Approaches to reduce chilling injury of fruits and vegetables. Hortic Rev. 15: 63-95.

Wang Z, Huang S, Jia C, Liu J, Zhang J, Xu, B, Jin Z (2013) Molecular cloning and expression of five glutathione $\mathrm{S}$ transferase (GST) genes from banana (Musa acuminata $\mathrm{L}$. AAA group, cv. Cavendish). Plant Cell Rep. 32(9): 1373.

Wendehenne D, Pugin A, Klessig DF, Durner J (2001) Nitric oxide: comparative synthesis and signalling in animal and plant cells. Trends Plant Sci. 6(4): 177-183.

Wild BL, Hood CW (1989) Hot dip treatments reduced chilling injury in long-term storage of Valencia oranges. HortSci. 24(1): 109-110.

Xu M, Dong J, Zhang M, Xu X, Sun L (2012) Cold-induced endogenous nitric oxide generation plays a role in chilling tolerance of loquat fruit during postharvest storage. Postharvest Biol Technol. 65: 5-12.

Zaharah SS, Singh Z (2011) Postharvest nitric oxide fumigation alleviates chilling injury, delays fruit ripening and maintains quality in cold-stored 'Kensington Pride' mango. Postharvest Biol Technol. 60(3): 202-210.

Zhu LQ, Zhou J, Zhu SH (2010) Effect of a combination of nitric oxide treatment and intermittent warming on prevention of chilling injury of 'Feicheng' peach fruit during storage. Food Chem. 121(1): 165-170.

Zhu S, Sun L, Liu M, Zhou J. (2008) Effect of nitric oxide on reactive oxygen species and antioxidant enzymes in kiwifruit during storage. J Sci Food. Agri. 88(13): 23242331. 